\title{
The Effect of Return on Equity and Earning Per Share on Stock Prices Period 2011 - 2017 (Case Study: Adaro Energy, Tbk.)
}

\author{
Khayatun Nufus Awaluddin Muchtar Rizka Melia Utami \\ Fakultas Ekonomi, Universitas Pamulang
}

\begin{abstract}
The purpose of this study is to know the Return On Equity (ROE), Earning Per Share (EPS) and the Share Price of PT. Adaro Energy, Tbk. and to determine the effect of Return On Equity (ROE), Earning Per Share (EPS) both partially and simultaneously on the stock price of PT. Adaro Energy, Tbk. $2011-2017$ period. This study uses secondary data, namely data taken indirectly from the source. The research method uses a quantitative descriptive approach and tests the classical assumptions which include, normality test, multicollinearity test, autocorrelation test, heteroscedasticity test, and data analysis including simple linear regression, multiple linear regression, test coefficient of determination, and hypothesis test ( $\mathrm{t}$ and $\mathrm{F}$ ) .

The partial test results ( $t$ test) for the ROE variable on stock prices obtained $t_{\text {hitung }}=2.522<2.570$ with a significant $0.053>0.05$ which means that Ho is accepted and H1 is rejected where ROE does not have a significant effect on stock prices, while for EPS variables on stock prices obtained thitung $4.316>2.570$ with a significance of 0.008 $<0.05$, which means that Ho is rejected and H2 is accepted where EPS has a significant influence on the Stock Price. Simultaneous tests (Test F) obtained Fcount 9,430>6,94 with a significance number of 0,031<0,05, which means that $\mathrm{Ho}$ is rejected and $\mathrm{H} 3$ is accepted where there is a significant effect between ROE and EPS simultaneously on Stock Prices. The Coefficient of Determination (KD) is indicated by the number 0.825 which concludes that ROE and EPS contribute $82.5 \%$ to the Stock Price, while the remaining $17.5 \%$ is influenced by other variables not examined.
\end{abstract}

Keywords: Return On Equity (ROE), Earning Per Share (EPS), and Stock Price.

DOI: $10.7176 /$ RJFA/10-10-14

Publication date:May $31^{\text {st }} 2019$

\section{Background}

An increasingly competitive business world requires companies to be able to adapt to avoid bankruptcy and excel in competition. To anticipate such competition, the company must maintain and improve its performance as an effort to maintain the continuity of its business. The usual effort is to implement a variety of strategic policies that produce efficiency and effectiveness for the company. These businesses require a lot of capital, including efforts to obtain and allocate these funds optimally. One place to obtain these funds is through the capital market.

Capital markets provide great opportunities, both for companies going public and for investors to portfolio their funds in the capital market. One of the advantages of the capital market is its ability to provide capital in the long run. To finance investments in long-term projects, it is appropriate for entrepreneurs to use funds from the capital market.

One important factor for investors in supporting the continuity of an industry is the availability of funds. Parties with excess funds will generally invest their funds at the level of returns according to the risks that must be borne by the investor. For investors, the rate of return (return) will be a very important factor because returns are the results obtained from an investment.

One of the most popular securities in the capital market is stocks. Shares are letters of proof of ownership of individuals or institutions within the company and are proof of taking part or participants in a public company (PT). Stocks are considered good if they are able to provide a realization return that is not too far from the expected return. According to Rusdin (2008: 66) The stock price is the price of a stock formed from the transactions that occur in the stock market that are determined by market participants with demand and supply of shares influenced by several factors. Stock prices show the performance of issuers moving in line with the performance of issuers. If the issuer's achievements are getting better, then the profits that can be generated from business operations are getting bigger. Such shares of the company are in demand by many investors and the share price of the issuers in question tends to rise, which indirectly reflects good quality companies.

According to Fahmi (2012: 99) Return On Equity (ROE) is a ratio that assesses the extent to which a company uses the resources it has to be able to provide a return on securities and is calculated by dividing profit after tax with its own capital. The greater the Return On Equity (ROE) of a company, will increase the company's stock price. A high ROE level indicates that the company is able to obtain a high level of profit compared to the level of equity, in other words, the ability of management to utilize the share capital owned for its operations so that it will generate additional profits for the company. ROE is very attractive to shareholders and prospective shareholders. 
The higher the ROE, the higher the value of the company, this is certainly an attraction for investors to invest in the company.

Sometimes the owner also wants data about the profits obtained for each share. The advantage of a sheet of stock is usually a profit indicator that is considered by investors which is the basic number needed to determine the stock price. Earning per Share (EPS) is a form of giving profits given to shareholders of each share they have (Fahmi). 2012: 97). Earning per Share is usually a concern for shareholders and management, the higher the EPS of a company means the greater the earnings that investors will receive from the investment, so for the company the increase in EPS has a positive impact on the price of its shares in the market.

The following is presented the Retrun On Equity, Earning Per Share and Share Prices of PT. Adaro Energy, Tbk. the period $2011-2017$ as follows:

Table 1.1

Average ROE, EPS, and Stock Price

At PT. ADARO ENERGY, Tbk. which is listed on the IDX Period $2011-2017$

\begin{tabular}{|c|c|c|c|}
\hline Tahun & ROE (\%) & EPS (Rp) & Harga Saham (Rp) \\
\hline 2011 & 22.61 & 156.03 & 1.770 \\
\hline 2012 & 12.80 & 116.50 & 1.590 \\
\hline 2013 & 7.18 & 88.70 & 1.090 \\
\hline 2014 & 5.62 & 69.17 & 1.040 \\
\hline 2015 & 4.50 & 65.74 & 515 \\
\hline 2016 & 9.00 & 140.56 & 1.695 \\
\hline 2017 & 13.11 & 204.71 & 1.860 \\
\hline
\end{tabular}

Source: Early 2018 survey

Based on the table, ROE, EPS and stock prices of PT. Adaro Energy, Tbk. from 2011 to 2015 it has decreased in a row. Then in 2015 to 2017 there was an increase again. So that in this case ROE, EPS and stock prices of PT. Adaro Energy, Tbk. period 2011 - 2017 has fluctuated.

From the brief description above, the author feels interested in raising the theme as the material for writing a thesis. For this reason, the author intends to write it in a thesis with the title "The Effect of Return on Equity (ROE) and Earning Per Share (EPS) on the Share Price of PT. Adaro Energy, Tbk. period 2011 - 2017 "

\section{Identification of Problems}

a. Return on Equity (ROE) in the financial statements of PT. Adaro Energy, Tbk. decreased in 2011-2015, and experienced an increase in 2015-2017

b. A decrease in Earning Per Share (EPS) in 2011-2015 and a significant increase in 2015-2017.

c. Stock prices declined in $2011-2015$.

\section{Limitation of Problems}

Given the breadth of the scope of this study, the authors limit the scope of the problem, namely: "Effect of Return on Equity (ROE) and Earning per Share (EPS) on the Share Price of PT. Adaro Energy, Tbk. period $2011-2017$ ".

This research was conducted at PT. Adaro Energy, Tbk. having his address at Jalan H.R Rasuna Said, Blok X-5, Kav. 1-2 Jakarta - 12950. By identifying financial statements for 2011 - 2017. This research will be conducted for 5 months from October 2018 to February 2019.

\section{Problem Formulation}

a. How does the ROE affect the stock price of PT. Adaro Energy, Tbk. the period 2011 - 2017 ?

b.. How is the influence of EPS on the stock price of PT. Adaro Energy, Tbk. the period $2011-2017$ ?

c. How are the effects of ROE and EPS together on the stock price of PT. Adaro Energy, Tbk. the period 2011 $2017 ?$

\section{Research Hypothesis}

Ho: $\beta 1=0$ is suspected that there is no influence between ROE on the stock price of PT.

Adaro Energy, Tbk. period of 2011-2017.

Ha: $\beta 1 \neq 0$ is thought to have an influence between ROE on the stock price of PT.

Adaro Energy, Tbk. period of 2011-2017.

Ho: $\beta 2=0$ is suspected that there is no influence between EPS on the stock price of PT.

Adaro Energy, Tbk. period of 2011-2017.

Ha: $\beta 2 \neq 0$ is thought to have an influence between EPS on the stock price of PT. Adaro Energy, Tbk. period of 2011-2017. 
Ho: $\beta 3=0$ is suspected that there is no influence between ROE and EPS on the stock price of PT. Adaro Energy, Tbk. period of 2011-2017.

Ha: $\beta 3 \neq 0$ is thought to have an influence between ROE and EPS on the stock price of PT. Adaro Energy, Tbk. period of 2011-2017.

\section{LITERATURE REVIEW}

Management: According to Malayu S.P Hasibuan (2012: 1) management is a tool to achieve the desired goals. Good management will facilitate the realization of corporate, employee and community goals. With management, usability and results of use elements - elements of management will be improved.

Financial Management. According to Bambang Riyanto (2013: 4) financial management is the overall activity concerned with the effort to get funds and use or allocate these funds.

Financial Reports According to the Indonesian Accounting Association (2012: 5) financial statements are structures that present financial position and financial performance in an entity. The general purpose of these financial statements for the public interest is the presentation of information about financial positions, financial performance (financial performance), and cash flow (cash flow) of entities that are very useful for making economic decisions for its users.

Financial Ratio. According to Kasmir (2012: 104) financial ratios are activities comparing the numbers in financial statements by dividing one number by another. Comparisons can be made between one component and components in one financial report or between components that exist between financial statements. Then the comparable numbers can be numbers in one period or several periods.

Return On Equity (ROE). According to Kasmir (2013: 204) The return on equity or return on equity is a ratio to measure net income after tax with own capital. This ratio shows the efficiency of the use of own capital. The higher this ratio, the better. This means that the position of the company owner is getting stronger, and vice versa. The formula for calculating Return On Equity (ROE) is as follows:

Return On Equity $=($ Net Profit $) /$ Equity x 100\%

Earning Per Share (EPS). According to Kasmir (2011: 207) Earning Per Share is a ratio to measure the success of management in achieving profits for shareholders. A low ratio means that management has not succeeded in satisfying shareholders, on the contrary with a high ratio, the welfare of shareholders increases. In other words a high rate of return. The formula for calculating Earning Per Share is as follows:

Earning Per Share $=($ Net Profit) $/$ (Outstanding Stock) x 100\%

Stock price. Stock prices are one indicator of company management. Success in generating profits will provide satisfaction for rational investors. A high enough stock price will provide benefits, namely in the form of capital gain and a better image for the company, making it easier for management to obtain funds from outside the company.

\section{METHODOLOGY}

The company that is the object of this research is PT. Adaro Energy, Tbk. with the address Menara Karya 23rd FI. Jln. H.R. Rasuna Said, Blok X-5, Kav. 1-2 Jakarta 12950, Tel: (021) 521-1265, 255-33040, Fax: (021) 579-44687, 579-44648,Homepage:www.adaro.com, The research used by researchers in the preparation of this thesis is descriptive quantitative, which is to discuss the problems faced by the company on the company's performance in terms of finance. Data - data used is quantitative data that is numerical data.

Data Collection Techniques. This study uses secondary data, namely data taken indirectly from the source but obtained from a second party or third party, in the form of literature studies in the form of books, journals and other documents that are related to literature studies and studying financial report books from objects that examined. Secondary data sources, namely the financial statements of PT. Adaro Energy, Tbk. Period $2011-2017$.

Analysis Method. The analytical method used in this study is quantitative methods. Quantitative data analysis is a form of analysis that uses numbers and calculations. The quantitative analysis used in this study is financial ratio analysis and statistical analysis.

\section{RESULTS AND DISCUSSION}

Normality Test 


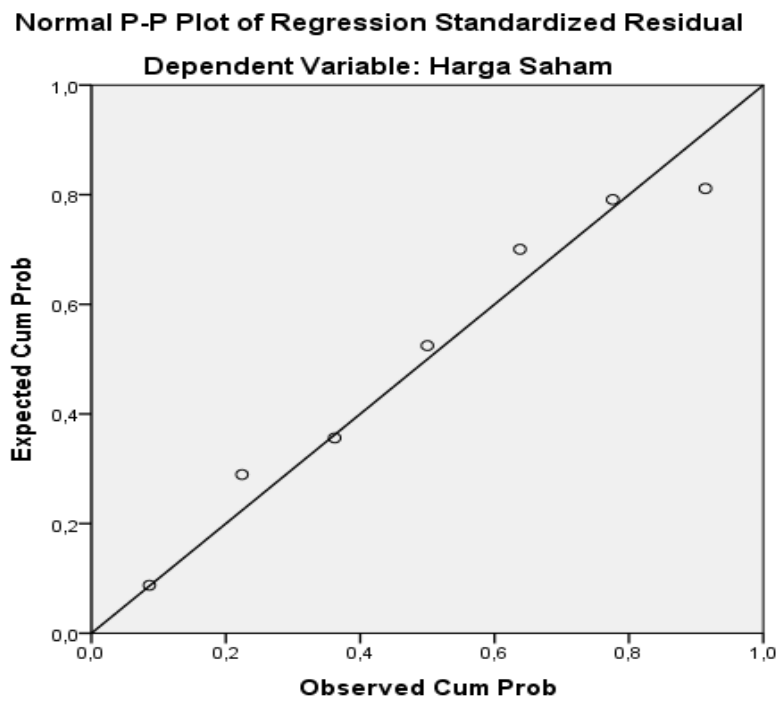

Picture 1

Normal Probability Plot

Source: SPSS 20 Processed Data

From the normal probability plot results above it can be seen that the plot points (data) spread around the diagonal line and follow the direction of the diagonal line, this indicates that the data used as material for this study has data that is normally distributed.

Tabel 1: Hasil Uji Multikolinearitas (Coefficients ${ }^{\text {a) }}$

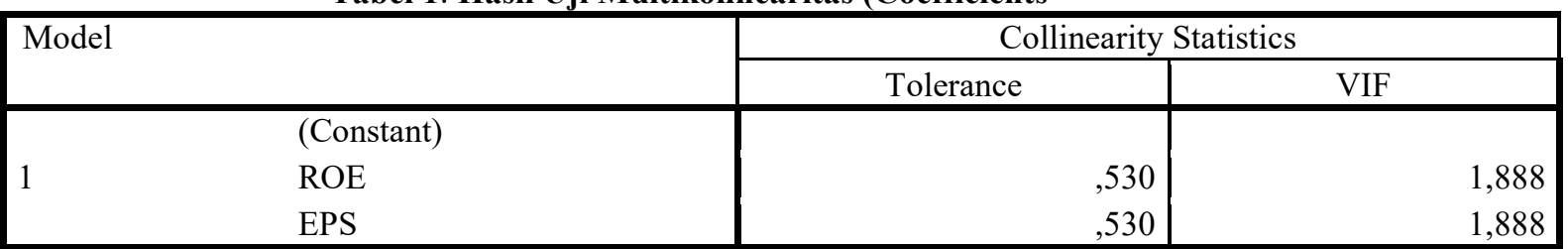

a. Dependent Variable: Harga Saham

Source: SPSS 20 Processed Data

From the results of the multicollinearity test above obtained the Tolerance value of all variables $>0.10$ and the VIF value of all variables $<10$, it can be concluded that there are no symptoms of multicollinearity in the regression model or in other words the data meet the classic assumption of multicollinearity.

\section{Autocorrelation Test}

Table 2: Autocorrelation Test with Durbin-Watson (Summary ${ }^{b}$ model)

\begin{tabular}{|l|c|r|r|r|r|}
\hline Model & R & R Square & Adjusted R Square & Std. Error of the Estimate & Durbin-Watson \\
\hline 1 &, $908^{\mathrm{a}}$ &, 825 &, 738 & 253,77967 & 3,197 \\
\hline
\end{tabular}

a. Predictors: (Constant), EPS, ROE b. Dependent Variable: Stock Price

Source: SPSS 20 Processed Data

Based on the results above, it is known that the DW value is 3.197. Then it cannot be concluded because the results of DW are 3.197, so the researchers continue the research using the Runs Test, as follows:

Table 3: Runs Test Test results are variable ROE, EPS and Stock Prices (Runs Test)

\begin{tabular}{|l|r|}
\hline & Unstandardized Residual \\
\hline Test Value $^{\mathrm{a}}$ & 15,68381 \\
Cases $<$ Test Value & 3 \\
Cases $>=$ Test Value & 4 \\
Total Cases & 7 \\
Number of Runs & 5 \\
$Z$ &, 061 \\
Asymp. Sig. (2-tailed) &, 952 \\
\hline
\end{tabular}

a. Median

Source: SPSS 20 Processed Data

Based on the Runs Test in table 3 above, a significance value of $0.952>0.05$ was obtained. Because the significant value is greater than 0.05 , it can be concluded that in this study there was no problem with 


\section{autocorrelation}

\section{Heteroscedasticity test}

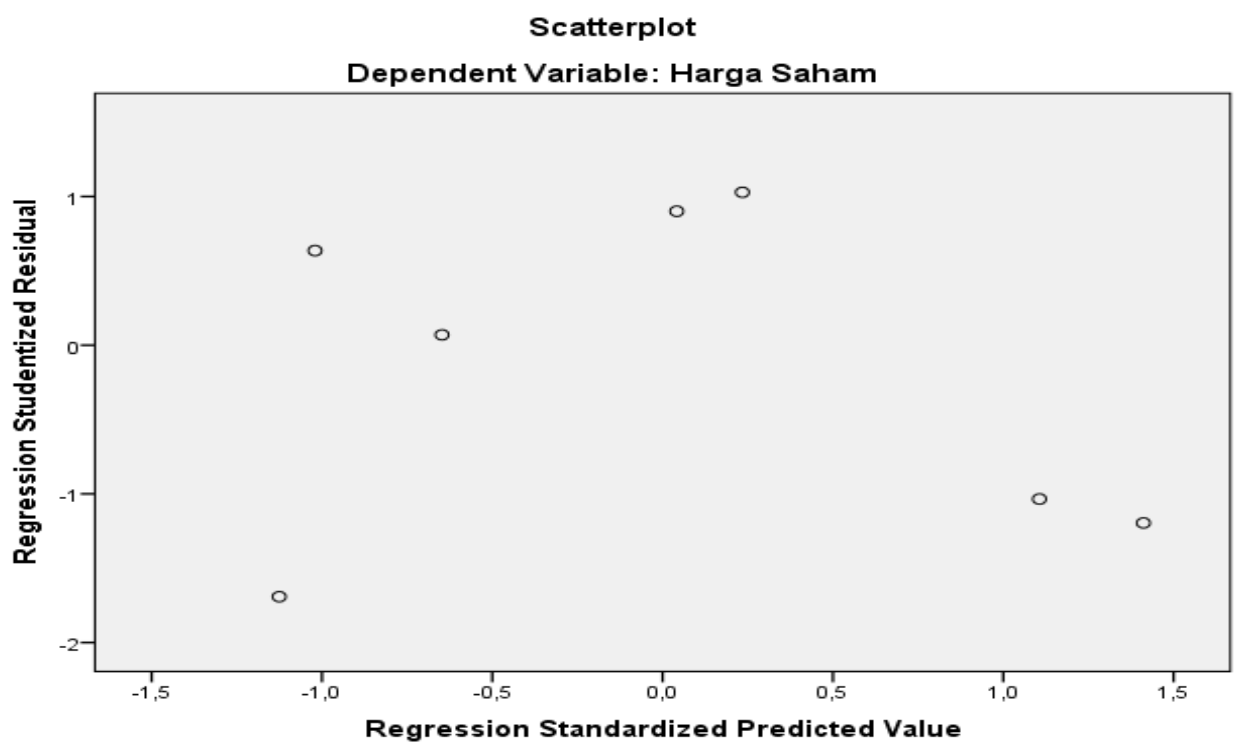

Source: SPSS 20 Processed Data

In the picture above it can be seen that the points spread randomly, do not form certain patterns and do not overlap. This identifies that there is no heteroscedasticity or that the data meets the classical assumption of heteroscedasticity.

Correlation Coefficient Test

Table 4: Correlation Coefficient Test Results

(Model Summary ${ }^{b}$

\begin{tabular}{|r|r|r|}
\hline \multicolumn{1}{|c|}{ R Square } & Adjusted R Square & Std. Error of the Estimate \\
\hline, 825 &, 738 & 253,77967 \\
\hline
\end{tabular}

a. Predictors: (Constant), EPS, ROE

b. Dependent Variable: Stock Price

Source: SPSS 20 Processed Data

In SPSS output in the Model Summary table, the correlation coefficient value is 0.908 , which means the level of relationship between variables Return on Equity (X1), Earning Per Share (X2) and stock price (Y), including at a very strong level of relationship.

\section{Determination Coefficient Test}

Table 5: Determination Test Results

Coefficients $^{\mathrm{a}}$

\begin{tabular}{|r|r|r|}
\hline \multicolumn{2}{|c|}{ Unstandardized Coefficients } & \multicolumn{2}{c|}{ Standardized Coefficients } \\
\hline B & Std. Error & Beta \\
\hline 728,022 & 287,131 & \\
59,661 & 23,656 &, 748 \\
\hline
\end{tabular}

a. Dependent Variable: Harga Saham

b. Dependent Variable: Stock Price

Source: SPSS 20 Processed Data

Based on the table above, the $\mathrm{R}$ square value is 0.825 or $82.5 \%$. This shows that the independent variables namely Return On Equity and Earning Per Share can provide $82.5 \%$ of the information needed to predict and explain the dependent variable, namely the stock price. While the remaining $17.5 \%$ is influenced by other variables not included in this regression model. 
Test of Hypotheses

1. Test $t$ (Partial Test)

Coefficients $^{\mathrm{a}}$

Table 6 t ROE Test Results

\begin{tabular}{|r|r|r|r|}
\hline \multicolumn{2}{|c|}{ Unstandardized Coefficients } & Standardized Coefficients & \multicolumn{2}{|c|}{$\mathrm{T}$} \\
\hline B & Std. Error & Beta & 2,536 \\
728,022 & 287,131 & & 2,522 \\
59,661 & 23,656 &, 748 & \\
\hline
\end{tabular}

a. Dependent Variable: Harga Saham

Source: SPSS 20 Processed Data

From the table above it is known that Return On Equity has a tcount of 2.522 while the table is 2.570 so that tcount $<\mathrm{t}$ table with a significant probability for the ROE variable is 0.053 greater than the significant level of 0.05 . Then Ho is accepted and $\mathrm{H} 1$ is rejected so that it can be concluded that partially ROE does not have a significant effect on stock prices.

Coefficients $^{\mathrm{a}}$

Table 7 T EPS Test Results

\begin{tabular}{|r|r|}
\hline \multicolumn{2}{|c|}{ Unstandardized Coefficients } \\
\hline B & \multicolumn{1}{|c|}{ Std. Error } \\
\hline 322,709 & 259,441 \\
8,677 & 2,011 \\
\hline
\end{tabular}

a. Dependent Variable: Harga Saham

Source: SPSS 20 Processed Data

Earning Per Share (EPS) has a tcount of 4.316 while $t$ table is 2.570 so that tcount $>t$ table with significant probability for EPS variable is 0.008 smaller than the significant level of 0.05 . Then Ho is rejected and $\mathrm{H} 2$ is accepted so that it can be concluded that partially EPS has a significant effect on stock prices.

\section{F (Simultaneous) Test}

The following are significant test calculations by testing using the F test calculated through the IBM SPSS 20 software tool:

Table 8

Test Results F

ANOVA ${ }^{\mathrm{a}}$

\begin{tabular}{|r|r|r|}
\hline \multicolumn{1}{|c|}{ df } & Mean Square & \multicolumn{1}{c|}{$\mathrm{F}$} \\
\hline 2 & 607352,476 & 9,430 \\
4 & 64404,119 & \\
6 & & \\
\hline
\end{tabular}

a. Dependent Variable: Harga Saham

b. Predictors: (Constant), EPS, ROE

Source: SPSS 20 Processed Data

From the ANOVA (Analysis of Variance) test or F test, it shows that the Fcount value is 9,430 with a significant value of 0,031 while Ftable is 6,94 with the $\mathrm{df}$ numerator $=2$, df the denominator $=4$ and significant level $\alpha=0,05$ so Fcount $>$ Ftabel. Thus, Ho is rejected and H3 is accepted. This means that there is a significant effect between Return On Equity (ROE) and Earning Per Share (EPS) simultaneously or jointly to the stock price. From table 4.14 it can be seen that a significant level of 0.031 is smaller than the specified level $\alpha=0.05$ identifying that there is a significant simultaneous influence between Return On Equity (X1) and Earning Per Share (X2) on the Stock Price (Y).

\section{CONCLUSIONS AND RECOMMENDATIONS}

\section{Conclusion}

1. Partially Return On Equity (X1) does not significantly influence the Share Price of PT. Adaro Energy, Tbk.

2. Partially Earning Per Share (X2) significantly influences the Share Price of PT. Adaro Energy, Tbk.

3. Simultaneously there is a significant influence between Return On Equity and Earning Per Share on the Share Price of PT. Adaro Energy, Tbk.

Suggestions

1. For Companies

Should need to pay attention to Return On Equity and Earning Per Share because both of these things 
become benchmarks of company performance, so that it can be seen the company's ability to produce a good level of profit so that it will increase stock purchase demand and stock prices will rise.

2. For Investors

Expected to pay attention to the ratios related to the increase in stock prices, and analyze how much influence both simultaneously and partially so that investors and prospective investors can choose the right decision for their investment.

3. For Further Researchers

It is expected to conduct research with more samples and variables, so that the results of the study have a broader and more accurate scope so that the company can see the factors that can influence stock prices.

\section{References}

Bambang Riyanto, 2013, "Dasar- Dasar Pembelanjaan Perusahaan", Edisi Keempat, BPFE-Yogyakarta, Yogyakarta.

Brigham dan Houston, 2010, "Dasar-dasar Manajemen Keuangan Buku 1", Edisi 11, Salemba Empat, Jakarta.

Brigham, Eugene F. dan Joel F. Houston, 2009, "Fundamentals of Financing Management", Edisi 12, SouthWestern Cengange Learning, Mason.

Danang Sunyoto, 2013, "Metodologi Penelitian Akuntansi", PT. Refika Aditama Anggota Ikapi, Bandung.

Dantes, Nyoman, 2012, "Metode Penelitian", Andi, Yogyakarta.

Darmadji dan Fakhrudin, 2011, "Pasar Modal di Indonesia", Edisi 3, Salemba Empat, Jakarta.

Duwi Priyatno, 2012, "Cara Kilat Belajar Analisis Data dengan SPSS 20", Edisi Kesatu, Andi, Yogyakarta.

Erni Ekawati, 2009, "Materi Pokok Manajemen Keuangan", Edisi Kesatu dan Cetakan Ketiga, Universitas Terbuka, Jakarta.

George R. Terry, 2013, "Principles of Management", Erlangga, Jakarta.

Ghozali, Imam, 2011, "Aplikasi Analisis Multivariate dengan Program SPSS", Badan Penerbit Universitas Diponegoro, Semarang.

Harahap, Sofyan Syafri, 2010, "Analisis Kritis Atas Laporan Keuangan", Rajawali Persada, Jakarta.

Hasibuan, Malayu, 2012, "Manajemen Sumber Daya Manusia", PT. Bumi Aksara, Jakarta.

Hery, 2015 "Analisis Laporan Keuangan", Center for Academic Publishing Services, Yogyakarta.

Horne, James C. Van dan John M Wachowicz, Jr, 2012, "Prinsip-prinsip Manajemen Keuangan", Edisi 13, Salemba Empat, Jakarta.

Horne, James C., 2013, "Prinsip-prinsip Manajemen Keuangan", Salemba Empat, Jakarta.

Ikatan Akuntan Indonesia, 2012, "Standar Akuntansi Keuangan", IAI, Jakarta.

Irham Fahmi, 2012, "Analisis Laporan Keuangan", Cetakan Kedua, Alfabeta, Bandung.

Irham Fahmi, 2013, "Analisis Laporan Keuangan", Cetakan Ketiga, Alfabeta, Bandung.

Kasmir, 2012, "Analisis Laporan Keuangan", PT. Raja Grafindo Persada, Jakarta.

2013, "Analisis Laporan Keuangan", PT. Raja Grafindo Persada, Jakarta.

2014, Analisis Laporan Keuangan", Edisi Satu dan Cetakan Ketujuh, PT. Raja Grafindo Persada, Jakarta.

Nor Hadi, 2011, "Corporate Social Responsibility", Graha Ilmu, Yogyakarta.

Rusdin, 2008, "Pasar Modal", Cetakan Kedua, Alfabeta, Bandung.

Sawidji Widoatmodjo, 2012, "Cara Cepat Memulai Investasi Saham Panduan bagi Pemula", PT. Elex Media Komputindo, Jakarta.

Singgih Santoso, 2012, "Analisis SPSS pada Statistik Parametrik", PT. Elex Media Komputindo, Jakarta.

Sri Ratna Hadi, 2013, "Sukses Membeli Saham Tanpa Modal Secara Otodidak", Laskar Aksara, Jakarta Timur.

Sugiyono, 2010, "Metode Penelitian Kuantitatif, Kualitatif, dan R\&D", Alfabeta, Bandung.

-2014, "Metode Penelitian Kuantitatif, Kualitatif, dan R\&D", Alfabeta, Bandung.

2017, "Metode Penelitian Kuantitatif, Kualitatif, dan R\&D", Alfabeta, Bandung.

Sutrisno, 2012, "Manajemen Keuangan Teori, Konsep dan Aplikasi", Ekonisia, Yogyakarta.

Tampubolon, Manahan P, 2013, "Manajemen Keuangan (Finance Management)", Mitra Wacana Media, Jakarta.

Tandelilin, Eduardus, 2010, "Portofolio dan Investasi Teori dan Aplikasi", Edisi Pertama, Kanisius, Yogyakarta.

Terry, George dan Leslie W. Rue, 2010, "Dasar-dasar Manajemen", Cetakan Kesebelas, PT. Bumi Aksara, Jakarta. 